\title{
The association between alexithymia and two dimensions of major depressive disorder: cognitive and somatic-affective
}

\author{
Maja Vilibić1,2, Anita Dostal2, Dalibor Karlović1,2,3 \\ ${ }^{1}$ Department of Psychiatry University Hospital Centre Sestre Milosrdnice, Zagreb, Croatia, \\ ${ }^{2}$ Catholic University of Croatia, Zagreb, Croatia, ${ }^{3}$ University of Zagreb, School of Dental \\ Medicine, Zagreb, Croatia
}

\begin{abstract}
Aim: To explore the association between alexithymia and two dimensions of major depressive disorder (MDD): cognitive and somatic-affective. Patients and methods. Unicentric, cross-sectional study included consecutive sample of 63 patients at the Department of Psychiatry (DoP), Sestre Milosrdnice University Hospital Centre, Zagreb, Croatia. Target population included outpatients with diagnosed MDD (F32 and F33, according to ICD-10). Inclusion critieria were: confirmed MDD diagnosis, age between 18 and 65 years, both genders, outpatient treatment at the DoP. The main outcome was the association between alexithymia, measured by total score on 20-item Toronto-Alexithymia scale (TAS-20), with two dimensions of MDD, cognitive and somatic-affective, measured by Beck Depression Inventory-II (BDI-II). Results: Both dimensions of BDI-II and the total severity of MDD symptoms were statistically significantly, although low, associated with alexithymia, and the differences between these two correlations were not (statistically) significant. However, in the multivariable model, the cognitive dimension $(b=0.64 ; \beta=0.48 ; p=0.002$; statistically significant at the false discovery rate of 0.05) was primarily associated with alexithymia, and the somatic-affective was not, after all cognitive aspects were controlled for $(b=-0.19 ; \beta=0-0.14 ; p=0.491$; not statistically significant, with the false discovery rate of 0.05 ). Conclusion: Alexithymia is primarily associated with a pure cognitive dimension of MDD after somatic-affective elements are excluded. Somatic-affective dimension of MDD is not associated with alexithymia after the cognitive elements were controlled for. Both dimensions, as well as the overall severity of MDD, are associated with alexithymia, but this association is relatively low.
\end{abstract}

Key words: alexithymia, depression, major depressive disorder, cognitive dimension, somatic-affective dimension

Copyright (c) 2021 KBCSM, Zagreb

e-mail: alcoholism.kbcsm@gmail.com•www.http://apr.kbcsm.hr

Correspondence to:

Maja Vilibić, Assistant Professor, MD, PhD

University Hospital Centre Sestre Milosrdnice,

Department of Psychiatry, Vinogradska 29, Zagreb, Croatia

E-mail: maja.vilibic@gmail.com

\section{Introduction}

Major depressive disorder (MDD) is the affective disorder characterised by three groups of depressive symptoms: emotional, cognitive and somatic. It is frequently accompanied with chronicity, somatic and/or 
psychiatric comorbidity, difficulties in functioning as well as quality of life decrease [1]. According to World Health Organization (WHO), currently in the world 322 millions of people suffer from depression [2]. Prevalence of MDD in Croatia is similar to those in other European neighbour countries, and was in previous years estimated by the Croatian Institute for Public Health (CIPH). Between 2014 and 2015, CIPH performed European Health Interview Survey (EHIS), as well as use of Patient Health Questionnaire-8 item (PHQ-8) within it. This Questionnaire was used as a triage instrument for possible depression for studies on non-clinical population. This self-rating instrument (PHQ-8) results certainly call for further clinical-psychiatric evaluation, collection of heteroanamnestic data as well as differential-diagnostic process. According to CIPH data, 1.5\% of surveyed population met criteria for major depressive episode, while $2.3 \%$ met criteria for some other depressive disorder. In addition, $96 \%$ of surveyed population did not met criteria for depressive disorder [3]. The term "alexithymia" is related to difficulties in recognizing and description of feelings [4]. It is a reflection of difficulties in cognitive-emotional processing and emotion control [5], and it can result in poorer understanding other people's emotions. Alexithymia prevalence in general population is about $10 \%$, while in patients with MDD could be up to $40 \%$ [6]. Causes of alexithymia are not clarified yet. According to big Danish twins study, it seems that about $30-33 \%$ of alexithymia is heritable [7]. Different previous studies found the association between alexithymia and MDD [8]. Clinical investigations, as well as everyday practice, suggest that MDD includes heterogeneous set of symptoms, and it seems that it could include various syndromes [9].
Based on such estimations, we decided to investigate the association between alexithymia and two dimensions of MDD: cognitive and somatic-affective. The aim of this study was to investigate the association of alexithymia, measured with 20-item Toronto Alexithymia Scale (TAS-20), with two MDD dimensions, measured with Beck Depression InventoryII (BDI-II).

\section{Patients and Methods}

A unicentric, observational, cross-sectional study was performed between April and June 2019 at the Department of Psychiatry, Sestre Milosrdnice University Hospital Centre, Zagreb, Croatia. Prior to study procedure, the Ethics Committee Approval was obtained, in accordance to Helsinki Declaration of World Health Organization [10]. Informed consent was signed by each participant prior to the study procedure. Target population included persons in the outpatient treatment with diagnosed MDD (categories: F 32 and F 33, according to International Classification of Diseases, 10th Revision ICD-10) [11]. Inclusion criteria included: confirmed MDD diagnosis, age between 18 and 65 years, both genders, outpatient treatment at the Department of Psychiatry. Exclusion criteria were: inability to use selected psychometric instruments and refusal for participation in the study. None of the screened patients met exclusion criteria. The consecutive sample was selected according to the time patients arrived to their outpatient treatment. Target statistical power was determined at $80 \%$, while the level of statistical significance at $\mathrm{p}<0.05$. Minimal association between alexithymia and two MDD dimensions that was considered clinically and theoretically relevant and which was wanted to 
be statistically significantly confirmed/tested was determined as Spearman's coefficient of range correlation $\varrho=0.35$. Moreover, according to this presumption, target sample was to include 61 participants. With anticipated / calculated up to $5 \%$ of wrong or incompletely filled data, the initial target size sample was increased to 66 participants. Sample size was calculated using computer program: G*Power version 3.1.9.2. The main outcome was the association between alexithymia, measured with total 20-item Toronto Alexithymia Scale (TAS-20) [12], and two MDD dimensions, measured by Beck Depression Inventory-II (BDI-II) [13]. Taylor and associates developed TAS-26 scale in 1985 [14]. The original 26 item scale was modified by Horton, Gewirtz and Kreutter in 1992 [15] and Bagly and associates in 1994 [16,17], into TAS-20. TAS-20 is a 20 -item scale containing five-degree Likert-type ascertainments, from: "completely disagree", via neutral "neither agree nor disagree" to "completely agree". Each participant evaluates to which extent each statement (within single item) is related to him/her. TAS-20 has a three-factor structure, theoretically consistent with alexithymia construct. Three factors include: (i) difficulties in identifying feelings and their distinction from somatic sensations, (ii) difficulties in describing feelings, and (iii) externallyoriented thinking. Yet, the main distinction between two versions of TAS instrument is in gawing up on dimension of "daily dreaming" in TAS-20. Despite more factor purity of such modified scale, as well as better other metrical characteristics, the modification may decrease scale validity in relation to original alexithymia concept [18]. The original version - TAS-26 - was validated in Croatian sample [18], while TAS-20, although without formally done validation study, was many time used

Association Between Alexithymia and Major Depressive Disorder in studies of various Croatian population samples. In our study, alexithymia was analysed as a total score on TAS-20. Two MDD dimensions were measured by BDI-II: a) cognitive dimension and b) somatic-affective dimension [13]. BDI-II was validated in Croatian, as well [19]. First scale was developed by Beck in 1961 [20]. After that, several modifications were done. The 21 item version used in our investigation was constructed in 1996 [13], and for each item patients rate various MDD symptom severity, by choosing one from four possible answers. Two-factors or two-dimensional BDI-II structure was confirmed in various studies [21]. Cognitive dimension of MDD is measured by followed BDI-II items: 1. sadness, 2. pessimism, 3. past failure, 5. guilty feelings, 6. punishment feelings, 7. self-dislike, 8. self-criticalness, 9. suicidal thoughts, 13. indecisiveness and 14. worthlessness. Somatic-affective dimension is measured by items: 4 . loss of pleasure, 10 . crying, 11. agitation, 12. loss of interest, 15. loss of energy, 16. changes in sleeping pattern, 17. irritability, 18. changes in appetite, 19. concentration difficulty, 20. fatigue, 21 . loss of interest in sex. Regarding our statistical analysis, the (main) hypothesis was checked by Spearman's coefficient of range correlation. Numerical variables distributions were described by median and interquartile range (IQR) and were presented by histograms and box-and-whiskers. The statistical significance of differences in arithmetic mean of results on TAS-20 between separate participants groups was calculated by analysis of variance.

\section{Results}

Three from 66 initially included patients did not fill TAS-20 adequately and therefore 
Table 1. Sociodemographic and vital participant characteristics $(n=63)$

\begin{tabular}{|c|c|c|}
\hline & $\mathrm{n}$ & $(\%)$ \\
\hline Age (years), median (IQR) & 53 & $(47-59)$ \\
\hline \multicolumn{3}{|l|}{ Gender } \\
\hline male & 21 & $(33.3)$ \\
\hline female & 42 & $(66.7)$ \\
\hline \multicolumn{3}{|l|}{ Education } \\
\hline \multicolumn{3}{|l|}{ elementary and high school } \\
\hline college & 47 & $(74.6)$ \\
\hline Marital status & 16 & $(25.4)$ \\
\hline married or in a stabile emotional relationship & 45 & $(71.4)$ \\
\hline never married, without partner & 18 & $(28.6)$ \\
\hline Number of household members, median (IQR) & 3 & $(2-4)$ \\
\hline \multicolumn{3}{|l|}{ Working status } \\
\hline employed or students & 40 & $(64.5)$ \\
\hline unemployed or retired & 22 & $(35.5)$ \\
\hline $\begin{array}{l}\text { Monthly household income } \\
\text { per one member (HRK), median (IQR) }\end{array}$ & 2.333 & $(1.286-3.500)$ \\
\hline Chronic somatic illness & 43 & $(68.3)$ \\
\hline $\begin{array}{l}\text { Body mass index }\left(\mathrm{kg} / \mathrm{m}^{2}\right) \\
\text { median }(\mathrm{IKR})\end{array}$ & 27 & $(24-30)$ \\
\hline \multicolumn{3}{|l|}{ Body mass index $\left(\mathrm{kg} / \mathrm{m}^{2}\right)$} \\
\hline normal $(<25.0)$ & 19 & $(30.2)$ \\
\hline overweight $(25,0-29,9)$ & 28 & $(44.4)$ \\
\hline obese $(\geq 30,0)$ & 16 & $(25.4)$ \\
\hline Smoking tobacco & 29 & $(46.0)$ \\
\hline
\end{tabular}

Data presented as number (percentage) of participants if not otherwise stated Abbreviation: $\mathrm{IQR}=$ interquartile range

There were no data regarding working status for one $(1,5 \%)$ participant.

were excluded from final analysis. Final analysis was done only with data from patients that had all the items answered, per protocol. Of 63 patients with all items answered, 42 were women $(66.7 \%)$ (Table 1$)$. Age ranged from 24 to 64 years, while median (IQR) was 53 (47-59) years.
MDD duration median (IQR) in our sample was 4 (2-6) years (Table 2). Most of the patients/participants were treated with selective serotonin reuptake inhibitors, 27 (42.9 $\%$, more than $90 \%$ with benzodiazepines, while nine $(14.3 \%)$ of them even with antipsychotics. 
Table 2. Participants clinical characteristics $(n=63)$

\begin{tabular}{lcc}
\hline & $\mathrm{n}$ & $(\%)$ \\
\hline MDD duration in years, median (IQR) & 4 & $(2-6)$ \\
\hline $\begin{array}{l}\text { Antidepressants in therapy } \\
\text { (number of medication) }\end{array}$ & & \\
monotherapy & 56 & $(88.9)$ \\
$\quad$ combination of two or more agents & 7 & $(11.1)$ \\
\hline Antidepressants in therapy & & \\
SSRI & 27 & $(42.9)$ \\
SNRI & 14 & $(22.2)$ \\
NaSSA & 12 & $(19.0)$ \\
MSS & 9 & $(14.3)$ \\
TCA & 7 & $(4.8)$ \\
$\quad$ MGS & 3 & $(20-41)$ \\
\hline Daily antidepressant dose (fluoxetine 40 mg & 24 & $(92.1)$ \\
equivalents), median (IQR) & & \\
Benzodiazepines in therapy & 58 & $(25.4)$ \\
Therapy with particular benzodiazepines & & $(50.8)$ \\
alprazolam & 16 & $(15.9)$ \\
diazepam & 32 & $(14.3)$ \\
other & 10 & $(74.6)$ \\
\hline Therapy with antipsychotics & 9 & \\
\hline Psychotherapy & 47 & \\
\hline Da & & \\
\hline
\end{tabular}

Data presented as number (percentage) of participants if not otherwise stated

Abbreviations: IQR = interquartile range; SSRI = Selective serotonin reuptake inhibitors; SNRI = serotonin-norepinephrine reuptake inhibitors; NaSSA = noradrenergic and specific serotonergic antidepressants; MSS = Serotonergic system modulators; TCA = tricyclic antidepressants; MGS = Glutamatergic system modulators.

\section{Alexithymia}

TAS results distribution did not statistical significantly deviate from normal (shapiro-Wilk test, $\mathrm{p}=0.838$ ) (Table 3). Arithmetic mean (standard deviation) of results on TAS20 was 60 (8.7), with total range of all results from 40 to 80 .
No statistically significant difference in TAS-20 results between analysed participants group was found (Table 3).

The association between alexithymia and total BDI-II result

Total result on BDI-II severity of depression scale and result on TAS-20 alexithymia 


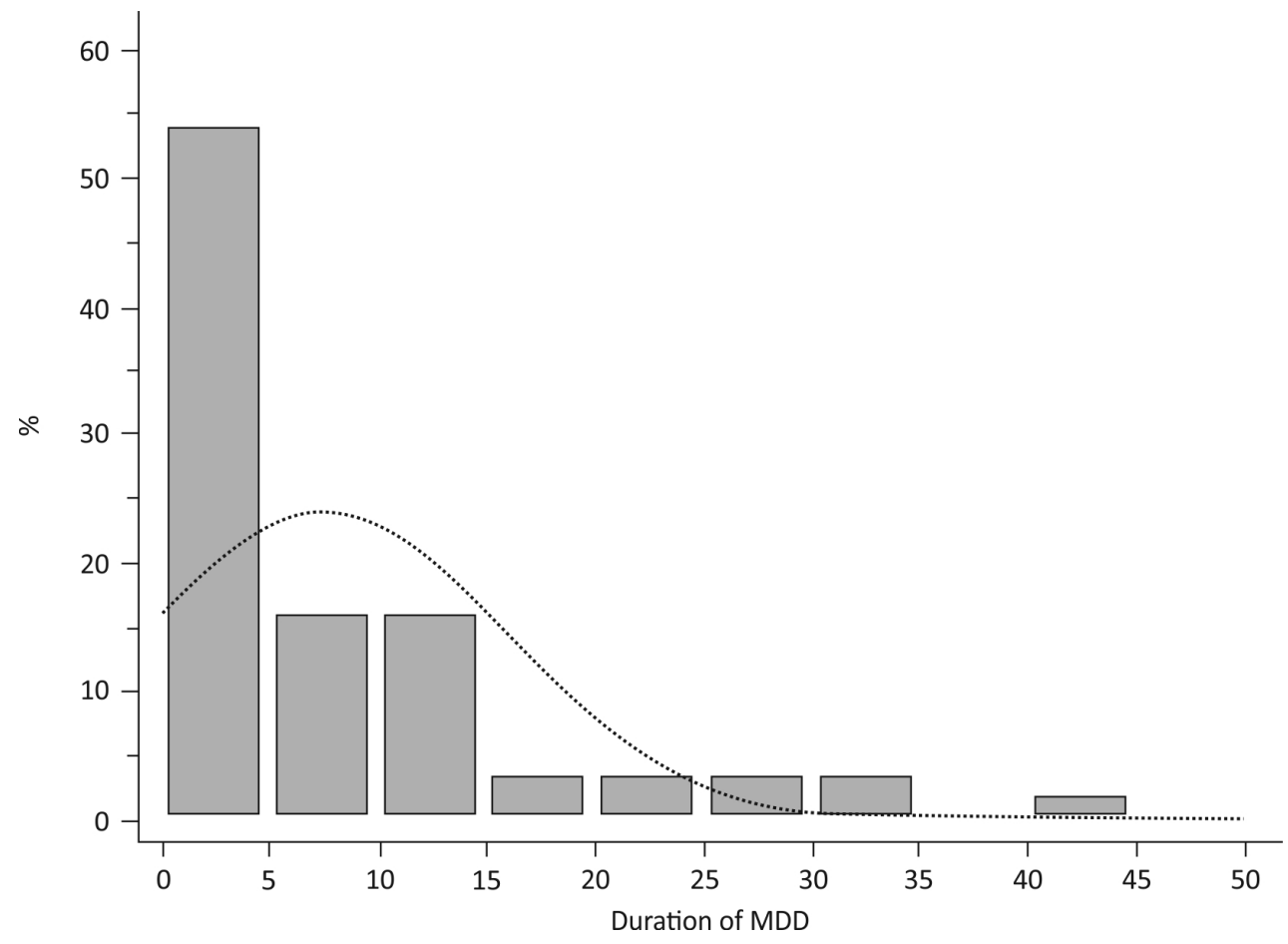

Figure 1. MDD duration distribution in years from first diagnose with normal distribution curve $(\mathrm{n}=63)$

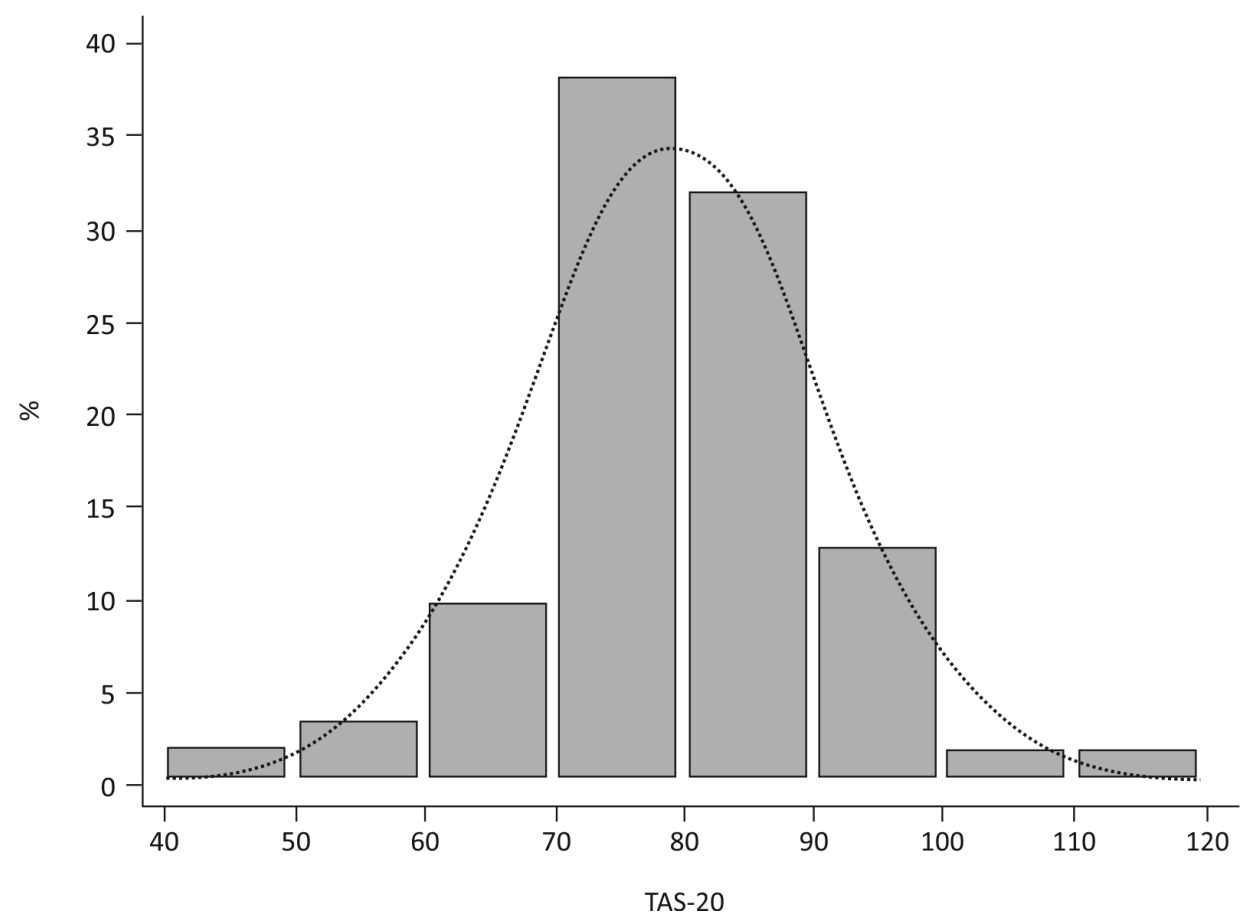

Figure 2. TAS-20 results distribution with normal distribution curve $(\mathrm{n}=63)$ 


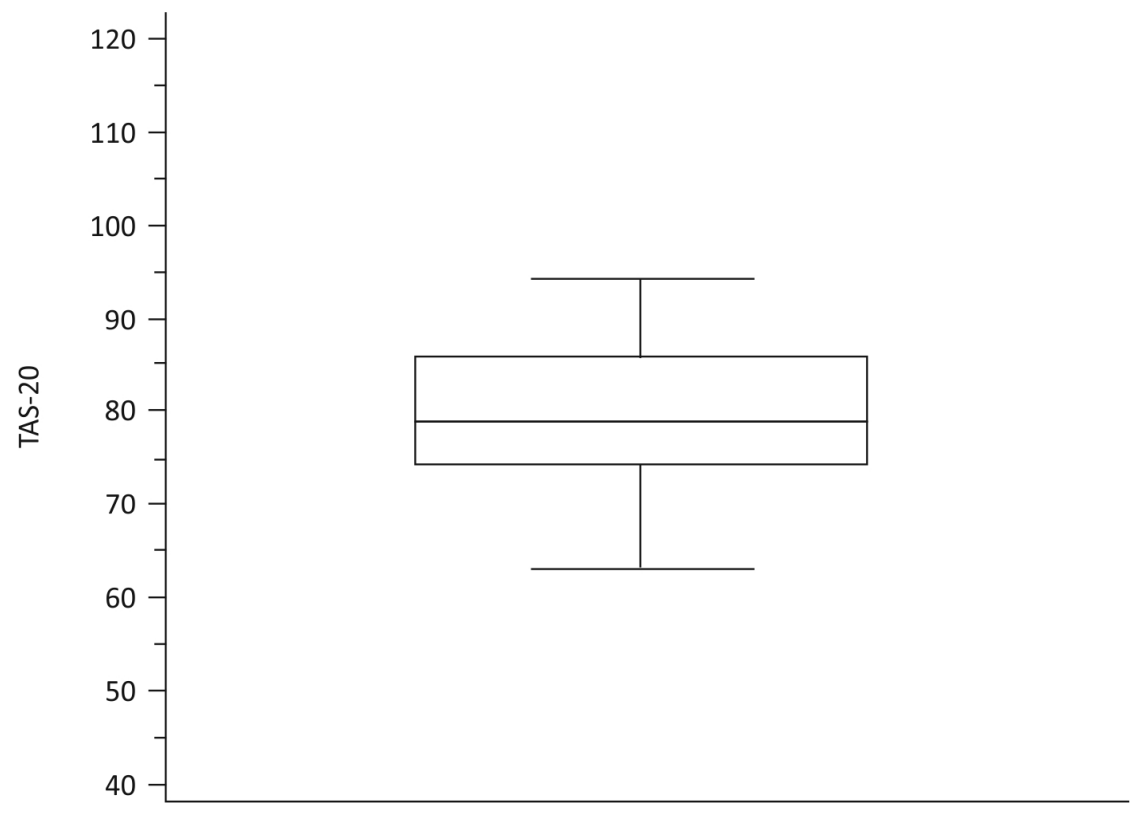

Figure 3. TAS-20 results distribution diagram of rectangles; bottom line is $1.5 \mathrm{IQR}$ below the median, rectangle is IQR, the middle line median, and the upper 1.5 IQR above the median; the vertical axis does not start on zero, but on the smallest result $(n=63)$

Table 3. Result on TAS-20 in different patient groups ( $\mathrm{n}=63$ )

\begin{tabular}{|c|c|c|c|c|c|c|}
\hline & $\mathrm{n}$ & $\mathrm{AM}$ & $(\mathrm{SD})$ & $\mathrm{p}$ & d & FDR \\
\hline \multicolumn{7}{|l|}{ Age (years) } \\
\hline$<45$ & 11 & 65 & $(10.3)$ & 0.211 & 0.46 & \\
\hline $45-54$ & 27 & 60 & $(9.0)$ & & & \\
\hline$\geq 55$ & 25 & 60 & $(7.3)$ & & & \\
\hline \multicolumn{7}{|l|}{ Gender } \\
\hline male & 21 & 60 & (8.5) & 0.583 & 0.14 & \\
\hline female & 42 & 61 & $(8.8)$ & & & \\
\hline \multicolumn{7}{|l|}{ Education } \\
\hline elementary or high school & 47 & 61 & (8.8) & 0.624 & 0.13 & \\
\hline college & 16 & 60 & (8.6) & & & \\
\hline \multicolumn{7}{|l|}{ Marital status } \\
\hline in stable relationship & 45 & 61 & (8.4) & 0.395 & 0.22 & \\
\hline alone & 18 & 59 & $(9.3)$ & & & \\
\hline
\end{tabular}


Table 3. (continued)

\begin{tabular}{|c|c|c|c|c|c|c|}
\hline & $\mathrm{n}$ & $\mathrm{AM}$ & $(\mathrm{SD})$ & $\mathrm{p}$ & $\mathrm{d}$ & FDR \\
\hline \multicolumn{7}{|c|}{ Number of household members } \\
\hline $1-2$ & 31 & 60 & $(8.0)$ & 0.689 & 0.22 & \\
\hline $3-4$ & 22 & 61 & $(9.0)$ & & & \\
\hline$\geq 5$ & 10 & 62 & $(10.6)$ & & & \\
\hline \multicolumn{7}{|l|}{ Working status } \\
\hline employed or students & 40 & 59 & $(8.3)$ & 0.208 & 0.33 & \\
\hline unemployed or retired & 22 & 62 & $(9.4)$ & & & \\
\hline \multicolumn{7}{|c|}{$\begin{array}{l}\text { Monthly household income } \\
\text { per one member (HRK), median (IQR) }\end{array}$} \\
\hline$<2000$ & 27 & 62 & (8.9) & 0.118 & 0.54 & \\
\hline 2000-3999 & 24 & 61 & $(8.0)$ & & & \\
\hline$\geq 4000$ & 12 & 56 & $(8.6)$ & & & \\
\hline \multicolumn{7}{|l|}{ Chronic somatic illness } \\
\hline no & 20 & 60 & $(9.5)$ & 0.937 & 0.00 & \\
\hline yes & 43 & 60 & $(8.4)$ & & & \\
\hline \multicolumn{7}{|l|}{ Body mass index $\left(\mathrm{kg} / \mathrm{m}^{2}\right)$} \\
\hline normal $(<25.0)$ & 19 & 62 & $(10.4)$ & 0.428 & 0.34 & \\
\hline overweight $(25,0-29,9)$ & 28 & 59 & $(7.3)$ & & & \\
\hline obesity $(\geq 30,0)$ & 16 & 62 & (8.8) & & & \\
\hline \multicolumn{7}{|l|}{ Smoking tobacco } \\
\hline no & 34 & 61 & (7.3) & 0.446 & 0,20 & \\
\hline yes & 29 & 60 & $(10.1)$ & & & \\
\hline
\end{tabular}

Data presented as number (percentage) of participants if not otherwise stated

Abbreviations: $\mathrm{n}=$ participants number; $\mathrm{AM}=$ arithmetic mean; $\mathrm{SD}=$ standard deviation; $\mathrm{p}=$ statistical significance calculated by variance analysis; $d$ = Cohen's $d$ calculated as standardized measure of effect size; FDR = statistically significant results after correction for false discovery rate.

There were no data regarding working status for $1(1.5 \%)$ participant

scale were significantly correlated (Spearman $\varrho=0.34 ; p=0.007$ ) (Figure 4). Despite statistically significant, that correlation was low.
The association between alexithymia and MDD cognitive dimension

Result on BDI-II cognitive dimension and result on TAS-20 alexithymia scale were 


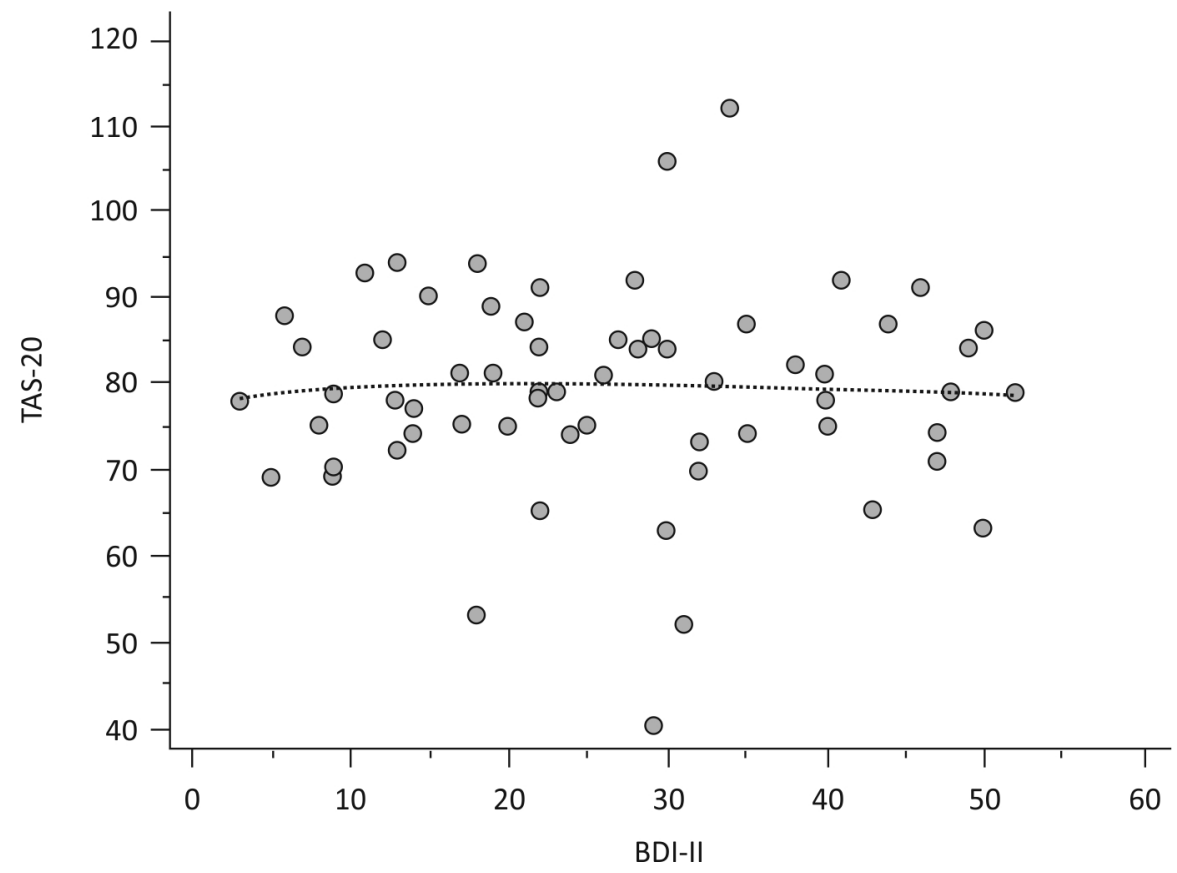

Figure 4. Dotted diagram of correlation on TAS-20 and BDI-II ( $\mathrm{n}=63)$

significantly correlated (Spearman's $\varrho=0.37$; $\mathrm{p}=0.003)$ (Figure 5). Despite statistical significance, that correlation was low.

The association between alexithymia and MDD somatic-affective dimension

Result on BDI-II somatic-affective dimension and result on TAS-20 alexithymia scale were significantly correlated (Spearman's $\varrho=0.27 ; \mathrm{p}=0.034$ ) (Figure 6). Despite statistical significance, that correlation was low.

Difference in association between alexithymia and cognitive as well as somatic-affective BDIIl dimension

On this sample level, correlation between TAS-20 and BDI-II somatic-affective dimension was lower than correlation between
TAS-20 and BDI-II cognitive dimension. The difference between the two correlations, correlation between TAS-20 with BDI-II cognitive dimension $(\varrho=0.37)$ and with BDIII somatic-affective dimension $(\varrho=0.27)$, was not significant $(\mathrm{Z}=1.46 ; \mathrm{p}=0.145)$. Correlation between two BDI-II dimensions was $\varrho=0.84 ; \mathrm{p}<0.001$.

But, when in linear multiple regression analysis both BDI-II dimensions were implemented together, it was shown that cognitive dimension was independently and significantly associated with TAS-20 result and even after correction for multiple testing, while somatic-affective was not (Figure 7). Semipartial correlation between BDI-II cognitive dimension and TAS-20 result was $\mathrm{sp}=0.28$, while correlation between somaticaffective dimension and TAS-20 result be- 


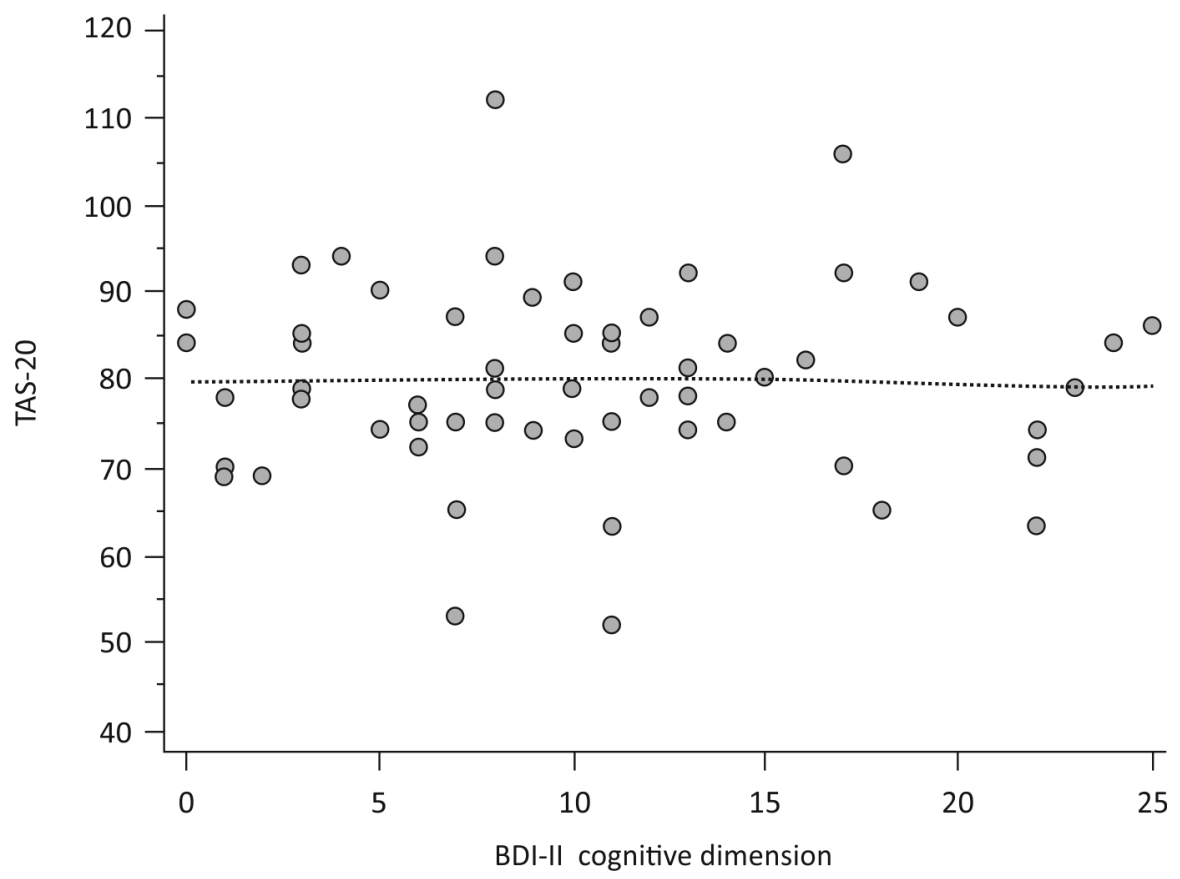

Figure 5. Dotted diagram of correlation between TAS-20 results and BDI-II cognitive dimension $(n=63)$

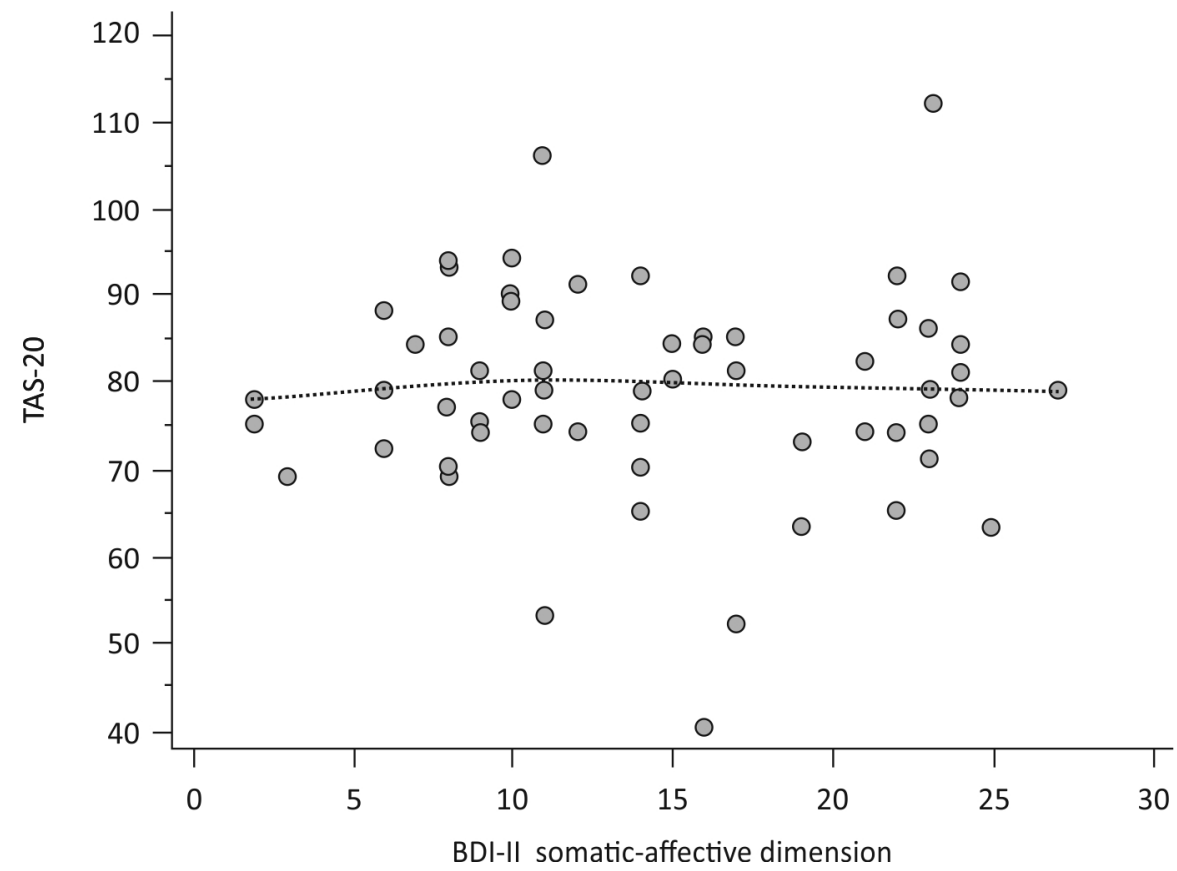

Figure 6. Dotted diagram of correlation between TAS-20 results and BDI-II somatic-affective dimension $(n=63)$ 
Figure 7. Linear multiple results regression on TAS-20 on two BDI-II dimensions ( $\mathrm{n}=63$ )

\begin{tabular}{lcccccccc}
\hline BDI-II dimension & $\mathrm{b}$ & $\left(\mathrm{CI}_{95 \%}\right)$ & s.e. & $\mathrm{t}$ & $\mathrm{B}$ & $\mathrm{p}$ & FDR $^{*}$ & $\mathrm{sp}$ \\
\hline Somatic-affective & -0.19 & $(-0.74-0.36)$ & 0.27 & -0.69 & -0.14 & 0.491 & - & -0.08 \\
\hline Cognitive & 0.64 & $(0.09-1.19)$ & 0.27 & 2.32 & 0.48 & 0.024 & significant & 0.28 \\
\hline
\end{tabular}

Abbreviations: $\mathrm{b}=$ nonstandardised regression coefficient; $\mathrm{CI}_{95 \%}=95 \%$ confidence interval of nonstandardised regression coefficient; s.e. $=$ standard error; $\beta=$ standardised regression coefficient; $\mathrm{t}=$ ratio between nonstandardised regression coefficient and its standard error; $\mathrm{p}=$ regression coefficient statistical significance; FDR $=$ False discovery rate; $\mathrm{sp}=$ semipartial correlation between BDI-II dimension and TAS-20 result

$* \mathrm{FDR}=0.05$

came negative, $\mathrm{sp}=-0.08$. This could mean that two BDI-II dimensions are associated particularly in that variance part which associates depression with alexithymia.

\section{Discussion}

The most important results review

This investigation found association between BDI-II cognitive dimension and TAS20 result independently regarding BDI-II somatic-affective dimension, respectively after the adjustment for somatic-dimension. Bivariably both BDI-II dimensions, as well as total depression/depressive symptoms severity measured by BDI-II, were significantly - although low - associated with alexithymia measured with TAS-20, but the difference between bivariable correlations between cognitive and somatic-affective dimensions and TAS-20 result was not statistical significantly different. There was no difference in TAS-20 results between sociodemographically different participants groups.

\section{Comparison with previous investigations}

Previous studies were focused on association between alexithymia and total MDD severity. American authors in their investigation published in 2010, on patient population aged $\geq 50$ years, regarding association between alexithymia and depression symptoms severity, found independent association between alexithymia and depression symptoms severity, after controlling demographic parameters (age, gender), cognitive functioning, as well as MDD burden. More pronounced alexithymia was associated with greater severity of depressive symptoms. Younger patients, patients with lower cognitive functioning as well as those with more pronounced disorder burden, had more pronounced/ more severe depressive symptoms. The authors also found that patients with higher scores/higher sums on Difficulties in recog- 
nising emotions subscale and on Difficulties in emotions expression subscale, but not those with higher scores/sums on Externally oriented thinking subscale, had higher total BDI-II score. Furthermore, they found that in patients older than 50 years alexithymia, and particularly difficulties in identification and emotions expression, was associated with more pronounced/more severe depressive symptoms [22].

Chinese authors metaanalysis from 2015 similarly showed close association between alexithymia, measured with TAS-20 and its two subscales: Difficulties identifying feelings subscale and Difficulties in describing feelings subscale, and depression [23]. In contrast to previous investigations that explored association between alexithymia and total MDD severity, this study aimed to explore the association between alexithymia and two MDD dimensions: cognitive and somatic-affective. In our investigation, total depressive symptoms severity measured by BDI-II were significantly, although low, associated with alexithymia, measured by TAS20. Our investigation found an association between cognitive BDI-II dimension and TAS-20 result independent regarding BDI-II somatic-affective dimension, respectively after adjustment for somatic-affective dimension. Alexithymia could be primarily associated with pure MDD cognitive dimension after somatic-affective elements are extracted, while MDD somatic-affective dimension could not be associated with alexithymia after cognitive elements are extracted. This result is very important for current, as well as for future clinical practice because it determines the way and type of interventions in treatment of patients with MDD and more pronounced/more severe alexithymia.

\section{Investigation limitations}

The first limitation is the weakness in alexithymia measuring/objectification. Despite TAS-20 is a well known, widely used and even language-standardized alexithymia measure, various weaknesses of the construct are well described in literature. Among the most important that should be mentioned is nonone-dimensionality. The TAS-20 scale was aimed to measure three different alexithymia dimensions: difficulty identifying feelings, difficulty describing feelings and externally oriented thinking. To the last listed TAS-20 dimension, various conceptual and psychometric reserves are addressed. Second limitation is related to heterogeneity of our sample, or more precisely, the fact that patients were included in investigation regardless of their treatment duration and total MDD duration. Although alexithymia could be independent regarding MDD duration, the result on TAS20 might vary in relation to MDD duration, course and therapy success. Based on available literature, one cannot reliably determine the probable pertaining systematic error, its intensity or influence on our conclusions. In future investigations, this problem should be analysed on samples large enough with an aim to allow stratified analysis within patient groups with recently diagnosed MDD and without antidepressant therapy, groups that are treated for a short period of time, groups that are treated for a long period of time and successfully, and finally groups with treatment resistance.

\section{Conclusion}

Alexithymia is primarily associated with a pure cognitive dimension of MDD after somatic-affective elements are excluded. Somatic-affective dimension of MDD is not as- 
sociated with alexithymia after the cognitive elements were controlled for. Both dimensions, as well as the overall severity of MDD, are associated with alexithymia but this association is relatively low.

Psychiatrists, medical nurses and other healthcare professionals should be familiar with the term "alexithymia", and all should be aware of limited ability of patients with more intensive alexithymia to recognise and verbalize their own feelings. This limited abil-

\section{References}

1. Kessler RC, Bromet EJ. The epidemiology of depression across cultures. Annu Rev Public Health. 2013;34:119-38.

2. World Health Organization. Depression and Other Common Mental Disorders: Global Health Estimates. Geneva: World Health Organization; 2017.

3. Hrvatski zavod za javno zdravstvo. Europska zdravstvena anketa u Hrvatskoj 2014.-2015. Zagreb: Hrvatski zavod za javno zdravstvo; 2016.

4. Nemiah JC, Sifneos PE. Psychosomatic illness: a problem in communication. Psychother Psychosom. 1970;18:154-60.

5. Taylor GJ, Bagby RM. Psychoanalysis and empirical research: the example of alexithymia. J Am Psychoanal Assoc. 2013;61:99-133.

6. Honkalampi K, Ruusunen A, Viinamäki H, Koivumaa-Honkanen $H$, Valkonen-Korhonen $\mathrm{M}$, Lehto SM. Dietary patterns are associated with the prevalence of alexithymia. Scand J Psychol. 2017;58:318-23.

7. Jørgensen MM, Zachariae R, Skytthe A, Kyvik K. Genetic and environmental factors in alexithymia: a population-based study of 8,785 Danish twin pairs. Psychother Psychosom. 2007;76:369-75.

8. Honkalampi K, Hintikka J, Tanskanen A, Lehtonen J, Viinamäki H. Depression is strongly associated with alexithymia in the general population. J Psychosom Res. 2000;48:99-104. ity can have direct influence on psychiatric interventions and therefore on therapeutic outcomes.

\section{Acknowledgements}

None.

\section{Conflicts of interest}

None to declare.
9. Borsboom D. A network theory of mental disorders. World Psychiatry 2017;16:5-13.

10. World Medical Association. World Medical Association Declaration of Helsinki: ethical principles for medical research involving human subjects. JAMA. 2013;310:2191-4.

11. World Health Organisation. ICD-10, International Statistical Classification of Diseases and Health Related Problems, 10th Revision, $1^{\text {st }}$ ed. Geneva: World Health Organisation; 1992.

12. Bagby RM, Taylor GJ, Parker JD. The Twenty-item Toronto Alexithymia Scale--II. Convergent, discriminant, and concurrent validity. J Psychosom Res. 1994;38:33-40.

13. Beck A, Steer R, Brown G. Manual for Beck Depression Inventory-II. San Antonio, USA: Psychological Corporation; 1996.

14. Taylor GJ, Ryan D, Bagby RM. Toward the development of a new self-report alexithymia scale. Psychother Psychosom. 1985;44:191-9.

15. Horton PC, Gewirtz H, Kreutter KJ. Alexithymia--state and trait. Psychother Psychosom. 1992;58:91-6.

16. Bagby RM, Taylor GJ, Parker JDA. The Twentyitem Toronto Alexithymia Scale--II. Convergent, discriminant, and concurrent validity. J Psychosom Res. 1994;38:33-40.

17. Bagby RM, Parker JD, Taylor GJ. The twenty-item Toronto Alexithymia Scale-I. Item selection and 
cross-validation of the factor structure. J Psychosom Res. 1994;38:23-32.

18. Lovko SK, Gelo J, Karlović D. Validation study of the Toronto alexithymia scale (TAS-26) in Croatian population. Acta Clin Croat. 2015;54:272-8.

19. Jakšić N, Ivezić E, Jokić-Begić N, Surányi Z, Stojanović-Špehar S. Factorial and diagnostic validity of the Beck Depression Inventory-II (BDIII) in Croatian primary health care. J Clin Psychol Med Settings. 2013;20:311-22.

20. Beck AT, Ward CH, Mendelson M, Mock J, Erbaugh J. An inventory for measuring depression. Arch Gen Psychiatry. 1961;4:561-71.
21. Huang C, Chen JH. Meta-Analysis of the Factor Structures of the Beck Depression Inventory-II. Assessment. 2015;22:459-72.

22. Bamonti PM, Heisel MJ, Topciu RA, Franus N, Talbot NL, Duberstein PR. Association of alexithymia and depression symptom severity in adults aged 50 years and older. Am J Geriatr Psychiatry. 2010;18:51-6.

23. Li S, Zhang B, Guo Y, Zhang J. The association between alexithymia assessed by the 20-item Toronto Alexithymia Scale and depression: A meta-analysis. Psychiatry Res. 2015;227:1-9.

\section{Povezanost aleksitimije i dvije dimenzije velikog depresivnog poremećaja: kognitivne i somatsko-afektivne}

Sažetak - Cilj. Istražiti povezanost aleksitimije s dvije dimenzije velikog depresivnog poremećaja (VDP): kognitivnom i somatsko-afektivnom. Materijali i metode. Provedeno je unicentrično, presječno istraživanje na susljednom uzorku 63 ispitanika na Klinici za psihijatriju KBC Sestre Milosrdnice, Zagreb, Hrvatska. Ciljana populacija bili su ambulantno liječeni bolesnici s dijagnosticiranim VDP (MKB-10: F32 i F33). Kriteriji uključivanja bili su: potvrđena dijagnoza VDP, dob od 18 do 65 godina, oba spola, ambulantno liječenje na Klinici za psihijatriju. Glavni ishod bila je povezanost aleksitimije mjerene ukupnim rezultatom Toronto ljestvice aleksitimije-20 (TAS-20) s dvije dimenzije VDP mjerenog Beckovim inventarom depresije-II (BDI-II): kognitivnom i somatsko-afektivnom. Rezultati. Istraživanjem se pokazalo da su bivarijabilno obje dimenzije BDI-II, kao i ukupna težina simptoma VDP statistički značajno iako nisko povezane s aleksitimijom te da razlike između tih dviju korelacija nisu statistički značajne. Međutim, u multivarijabilnom modelu pokazalo se da je s aleksitimijom primarno povezana kognitivna dimenzija $(b=0,64 ; \beta=0,48 ; p=0,002$; statistički značajno uz stopu lažnih otkrića od 0,05), dok somatsko-afektivna to nije, nakon što se iz nje izluče svi kognitivni aspekti (b=-0,19; $\beta=0-0,14 ; p=0,491 ;$ nije statistički značajno uz stopu lažnih otkrića od 0,05). Zaključak. Čini se da je aleksitimija primarno povezana s čistom kognitivnom dimenzijom VDP nakon što se iz nje izluče somatsko-afektivni elementi, odnosno da somatsko-afektivna dimenzija VDP nije povezana s aleksitimijom nakon što su izlučeni kognitivni elementi. Obje dimenzije, kao i ukupna težina VDP, povezani su s aleksitimijom, no ta je povezanost razmjerno niska.

Ključne riječi: aleksitimija, depresija, veliki depresivni poremećaj, kognitivna dimenzija, somatsko-afektivna dimenzija. 